\title{
Concentrations of nonesterified fatty acids and glucose in blood of periparturient dairy cows are indicative of pregnancy success at first insemination
}

\author{
H. A. Garverick, ${ }^{11}$ M. N. Harris, ${ }^{*}$ R. Vogel-Bluel, ${ }^{*}$ J. D. Sampson, ${ }^{*}$ J. Bader, ${ }^{*}$ W. R. Lamberson, ${ }^{*}$ \\ J. N. Spain, ${ }^{*}$ M. C. Lucy, ${ }^{\star}$ and R. S. Youngquist $†$ \\ *Department of Animal Sciences, and \\ †Department of Veterinary Medicine and Surgery, University of Missouri, Columbia 65211
}

\begin{abstract}
Greater blood concentrations of nonesterified fatty acids (NEFA) and lesser blood concentrations of glucose are indicative of the normal process of nutrient partitioning that occurs in early postpartum dairy cows. The objective was to determine the relationship between blood NEFA and glucose concentrations and subsequent conception at first insemination in postpartum dairy cows. Holstein $(\mathrm{n}=148)$ and Guernsey (n $=8$ ) dairy cows were blood sampled at approximately d 10, 7, and 3 prepartum, on the day of calving and 3, 7, 14, and $21 \mathrm{~d}$ postpartum for measurement of NEFA and glucose concentrations. Serum and plasma were harvested and used for measurement of NEFA and glucose concentrations, respectively. Cows were given a presynchronization treatment (2 injections of $\mathrm{PGF}_{2 \alpha} 14$ $\mathrm{d}$ apart) with the second $\mathrm{PGF}_{2 \alpha}$ injection occurring 14 $\mathrm{d}$ before the initiation of the timed AI (TAI) protocol. Blood for determination of progesterone concentrations was collected at each presynchronization injection and at the initiation of the TAI protocol that was used for first insemination (74 $\pm 7 \mathrm{~d}$ postpartum). Cows were considered noncycling if serum progesterone concentrations at the 2 presynchronization $\mathrm{PGF}_{2 \alpha}$ injections (d 37 and $51 \pm 7$ postpartum) and at the initiation of the TAI protocol (d $65 \pm 7$ postpartum) were $\leq 1 \mathrm{ng} / \mathrm{mL}$, and there was no indication of ovulation or presence of a corpus luteum by ultrasound examination at the initiation of the TAI protocol. Pregnancy was determined at $33 \mathrm{~d}$ and again at $61 \mathrm{~d}$ after first insemination by using ultrasound. Across all days, serum NEFA and plasma glucose concentrations were not different between cows that ovulated before the initiation of the TAI program (cycling) compared with those that did not ovulate (noncycling). Serum NEFA concentrations,
\end{abstract}

Received April 13, 2012

Accepted September 6, 2012.

${ }^{1}$ Corresponding author: garverickh@missouri.edu however, were less and plasma glucose concentrations were greater during the early postpartum period for cows that subsequently became pregnant at first insemination compared with those that failed to become pregnant. Logistic regressions were used to predict the probability of pregnancy based on NEFA and glucose concentrations from individual days. The prediction with the greatest likelihood ratio was for d 3 postpartum NEFA and glucose concentrations. Nutritional status during the early postpartum period (within 1 wk after calving), as indicated by blood NEFA and glucose concentrations, may affect subsequent fertility by a mechanism that is independent from interval to first ovulation.

Key words: nonesterified fatty acid, glucose, periparturient, fertility

\section{INTRODUCTION}

Pregnancy per AI (P/AI) in lactating dairy cows has decreased relative to those recorded more than 50 years ago (Butler and Smith, 1989; Stevenson et al., 2008). Changes in the physiology and management of dairy cattle seem to contribute to the decrease in fertility (Royal et al., 2002; Chagas et al., 2007). A tremendous demand exists for nutrients during lactation and the associated severity of negative energy balance during early lactation has been one mechanistic explanation for lower fertility in dairy cows (Beam and Butler, 1999; Butler, 2000). Cows with greater NEFA are presumably mobilizing more adipose tissue to support milk production and are losing more body condition compared with cows with lesser NEFA (Beever, 2006). Cows with NEFA and BHBA concentrations in blood above a critical threshold can be predicted to have a greater incidence of diseases such as ketosis and displaced abomasum (Ospina et al., 2010a) These diseases were associated with reduced postpartum reproductive performance (Ospina et al., 2010c). In addition to fat mobilization in early postpartum cows, 
liver gluconeogenesis increases to provide glucose for milk lactose synthesis (Bauman and Currie, 1980). The large demand for glucose may decrease the amount of glucose available to other tissues in the body, including those that that are involved in postpartum reproduction (Wathes et al., 2011; Green et al., 2012).

Follicles that are growing shortly after calving reach ovulatory size when cows are 60 to $90 \mathrm{~d}$ postpartum (approximate time of first insemination; Webb et al., 2003). The integrity of follicles and their resident oocytes may be compromised in postpartum cows because extreme concentrations of circulating hormones and metabolites can potentially affect their function (Britt, 1994; Leroy et al., 2008a,b). At the same time, the uterus is undergoing involution and repair, a process that is controlled in part by immune cells that are suppressed in postpartum cows (LeBlanc, 2010). Cows that develop metritis have lesser DMI during the prepartum and postpartum periods, and metritis is a risk factor for infertility in dairy cows (Gumen et al., 2011). Nutritional events that occur during the periparturient and postpartum periods, therefore, can alter ovarian, oviductal, and uterine function and potentially affect subsequent fertility in the postpartum cow. We hypothesized that cows that failed to cycle or failed to conceive to first insemination would have postpartum blood NEFA and glucose concentrations that indicated a greater severity of negative energy balance. The objective of this study, therefore, was to assess blood NEFA and glucose relative to the cycling and first service pregnancy status of the cow.

\section{MATERIALS AND METHODS}

\section{Animals and Feeding}

The experimental procedures were approved by the University of Missouri Animal Care and Use Committee (reference no. 3899). Holstein $(\mathrm{n}=148)$ and Guernsey $(\mathrm{n}=8)$ cows at the University of Missouri Foremost Dairy Research Center (Columbia) were used in the study. The cows were first or greater parity and were deemed suitable for postpartum breeding by the examining veterinarian (R. S. Youngquist). Data were collected during a 2-yr period from December 1 through June 20 of each year. The Foremost farm consists of approximately 225 cows with an annual rolling herd average in excess of $10,000 \mathrm{~kg}$ of milk. Daily milk weights were available for 70 cows during the first year of the study. Body condition scores $(1=$ thin to $5=$ fat; Wildman et al., 1982) were determined at parturition and at first breeding postpartum. Cows were housed in a freestall barn with access to an exercise lot be- fore calving and fed a TMR that was formulated for late pregnant, nonlactating cows (dry cow diet). After calving, cows were housed in a freestall barn and fed a lactating cow TMR. The TMR was formulated to meet or exceed NRC (2001) recommendations. Feed was provided twice daily; once at approximately $0800 \mathrm{~h}$ and a second time at $1600 \mathrm{~h}$. After calving, cows were milked twice daily at 0400 and $1600 \mathrm{~h}$. The experiment began $10 \mathrm{~d}$ before expected calving and continued until a second pregnancy exam at $61 \mathrm{~d}$ after first AI.

\section{Blood Collection Schedule and Assays for NEFA and Glucose}

Blood samples were collected on d 10, 7, and 3 before expected calving (and every $3 \mathrm{~d}$ until calving), on the day of calving and on $\mathrm{d} 3,7,14$, and 21 after calving by puncture of the medial caudal coccygeal vein or artery. For plasma (glucose determination), blood was collected into EDTA-coated tubes, cooled on ice, driven to the laboratory, centrifuged at $1500 \times g$, and plasma was stored frozen at $-20^{\circ} \mathrm{C}$ (total time 2 to 4 $\mathrm{h}$ from collection to freezing). Blood glucose concentrations were measured for cows on the first year of the study $(\mathrm{n}=89)$. For serum (NEFA determination), blood was collected into noncoated tubes, allowed to clot overnight, and processed for $-20^{\circ} \mathrm{C}$ storage using the procedures described for plasma. Plasma glucose concentrations were determined enzymatically with the glucose oxidase method (Thermo Fisher Scientific, Waltham, MA). Absorbance was quantified using a Beckman DU-65 spectrophotometer (Beckman Instruments, Brea, CA). Serum NEFA concentrations were determined using a NEFA C kit (Wako Diagnostics, Richmond, VA). Colorimetric development was quantified on a Tecan rainbow plate reader (Tecan US Inc., Durham, NC).

\section{Timed Al Program}

All cows were enrolled in a Presynch Ovsynch (or Presynch Cosynch) protocol. At $37 \pm 7$ d postpartum, cows were injected with $\mathrm{PGF}_{2 \alpha}$ (Lutalyse; $25 \mathrm{mg}$ of dinoprost tromethamine, i.m.; Pfizer Animal Health, New York, $\mathrm{NY}$ ) and a second injection of $\mathrm{PGF}_{2 \alpha}$ was given $14 \mathrm{~d}$ later (51 $\pm 7 \mathrm{~d}$ postpartum). Fourteen days later (65 $\pm 7 \mathrm{~d}$ postpartum) the Ovsynch-Cosynch protocol was initiated. Cows were given the first injection of $\mathrm{GnRH}$ (100 $\mu \mathrm{g}$, OvaCyst; IVX Animal Health Inc., St. Joseph, MO) followed $7 \mathrm{~d}$ later with another injection of $\mathrm{PGF}_{2 \alpha}$ (72 $\pm 7 \mathrm{~d}$ postpartum). Noncycling cows (absence of a corpus luteum or no indication of ovulation by transrectal ultrasonography (Aloka $500 \mathrm{~V}$ with a $5.0 \mathrm{MHz}$ 
linear-array transducer; Corometrics Medical Systems Inc., Wallingford, CT) at either the presynchronization injections of $\mathrm{PGF}_{2 \alpha}$ or at the initiation of the OvsynchCosynch protocol) received a controlled internal drug release (CIDR) device (controlled intravaginal device containing progesterone; Pfizer Animal Health) at the first injection of $\mathrm{GnRH}$. The CIDR was removed at the subsequent injection of $\mathrm{PGF}_{2 \alpha}$ (Stevenson et al., 2008). A final injection of $\mathrm{GnRH}$ was given at $48 \mathrm{~h}(\mathrm{~d} 74 \pm 7$ postpartum) following the final $\mathrm{PGF}_{2 \alpha}$ injection. Cows were artificially inseminated at the second injection of GnRH (Cosynch) or $24 \mathrm{~h}$ later (Ovsynch). Pregnancy was determined by ultrasonography. A cow was diagnosed pregnant if an embryo with a heartbeat was detected. Cows that were pregnant at the first diagnosis (33 d after AI) underwent a confirmatory ultrasound examination at $61 \mathrm{~d}$ after AI.

\section{Transrectal Ultrasonography and Blood Collection Schedule for Progesterone Assay}

The ovaries and uterus were examined by transrectal ultrasonography when injections were given during the presynchronization and Ovsynch-Cosynch procedures and $1 \mathrm{wk}$ following AI to assess the presence of a corpus luteum. Blood samples were collected at the time of each presynchronization $\mathrm{PGF}_{2 \alpha}$ injection (i.e., 28 and $14 \mathrm{~d}$ before the start of Ovsynch-Cosynch) and when injections were given during the Ovsynch-Cosynch procedure $\left[\mathrm{d} 0(\mathrm{GnRH})\right.$, d $7\left(\mathrm{PGF}_{2 \alpha}\right)$, and d $\left.9(\mathrm{GnRH})\right]$. Serum concentrations of progesterone were measured by RIA (Progesterone Coat-a-Count kit, Diagnostic Products Corp., Los Angeles, CA; Kirby et al., 1997). Intra- and interassay coefficients of variation were 3.0 and $10.2 \%$, respectively.

\section{Statistical Analyses}

The study was conducted during a 2-yr period. Some cows $(\mathrm{n}=27)$ were sampled during 2 consecutive lactations and were considered independent for the purpose of statistical analyses. Comparisons of serum NEFA and plasma glucose concentrations were made between cows that had initiated ovulatory ovarian cycles (cycling) and those that had not (noncycling) and between cows that were pregnant after first insemination postpartum compared with those that were not pregnant after first insemination. Cows were considered noncycling if serum progesterone concentrations at the 2 presynchronization $\mathrm{PGF}_{2 \alpha}$ injections (d 37 and $51 \pm$ 7 postpartum) and at the initiation of the OvsynchCosynch protocol (d $65 \pm 7$ postpartum) were $\leq 1 \mathrm{ng} /$ $\mathrm{mL}$, and there was no indication of ovulation or pres- ence of a corpus luteum by ultrasound examination at the presynchronization examinations or at the initiation of the Ovsynch-Cosynch protocol. No difference existed in conception rates for Ovsynch compared with Cosynch. The 2 treatments, therefore, were combined for statistical analysis. In addition, 4 cows pregnant at the $\mathrm{d} 33$ examination were diagnosed not pregnant at d 61. Given the small number of cows in which pregnancy was lost, analyses were conducted on the d 33 pregnancy diagnoses. Serum NEFA and plasma glucose concentrations were analyzed by fitting the fixed effects of day, cycling, or pregnancy status and the interaction of day with cycling or pregnancy status and the random effect of cow in a mixed model ANOVA for repeated measures (SAS Institute Inc., Cary, NC). Logistic regressions were used to determine the probability of pregnancy based on serum NEFA and plasma glucose concentrations from each of the individual days. Day 3 values are reported as they were found to be the most predictive based on the likelihood ratios of the regressions. Milk production and BCS were analyzed by fitting the effects of cycling or pregnancy status in an ANOVA. The effect of cyclicity on pregnancy status after timed AI was tested by using the chi-squared test. Statistical significance was declared at $P<0.05$ unless stated otherwise.

\section{RESULTS}

\section{Pregnancy per Al}

Cows were inseminated on $\mathrm{d} 74$ or $75 \pm 7$ postpartum. Thirty-nine cows $(25 \%)$ cows had not ovulated before the initiation of the Ovsynch-Cosynch protocol (Table 1). The overall P/AI was 33\% $(\mathrm{n}=51)$. Cycling cows tended to have a greater $\mathrm{P} / \mathrm{AI}$ compared with noncycling cows $(P<0.06$; Table 1$)$.

\section{NEFA and Glucose Concentrations}

An effect of day on serum NEFA concentrations $(P$ $<0.001)$ was observed. Serum NEFA concentrations

Table 1. Pregnancy status after first insemination for cows that ovulated (cycling cows) or did not ovulate (noncycling cows) before the initiation of the timed AI treatments

\begin{tabular}{lrrr}
\hline & & \multicolumn{2}{c}{ Pregnancy status } \\
\cline { 3 - 4 } & & & \multicolumn{1}{c}{$\begin{array}{c}\text { Not } \\
\text { pregnant }\end{array}$} \\
Cyclicity status & $\mathrm{n}$ & Pregnant & $74(63)$ \\
Cycling, n (\%) & 117 & $43(37)$ & $31(79)$ \\
Noncycling, n (\%) & 39 & $8(21)$ & $105(67)$ \\
Total, n (\%) & 156 & $51(33)$ & \multicolumn{1}{c}{ pros } \\
\hline
\end{tabular}


A

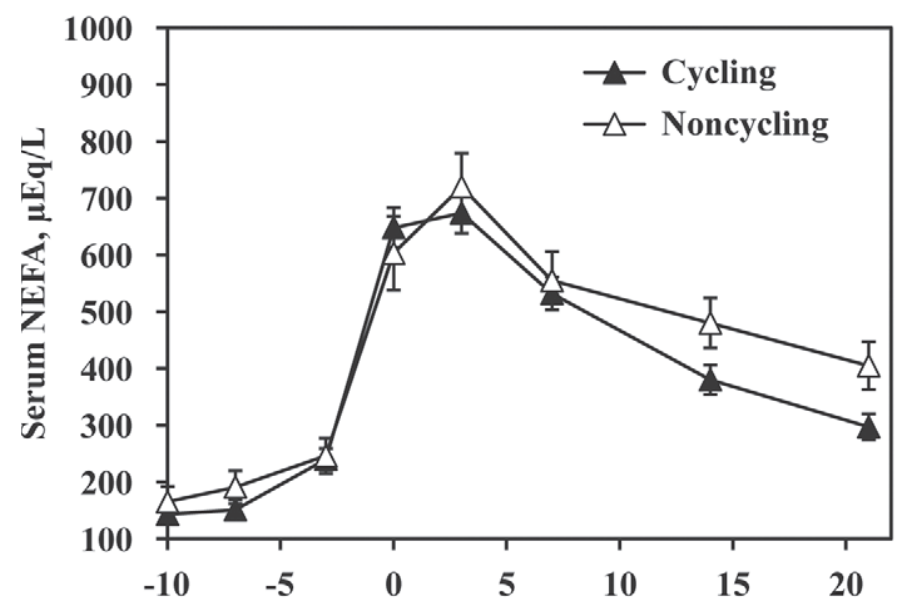

B

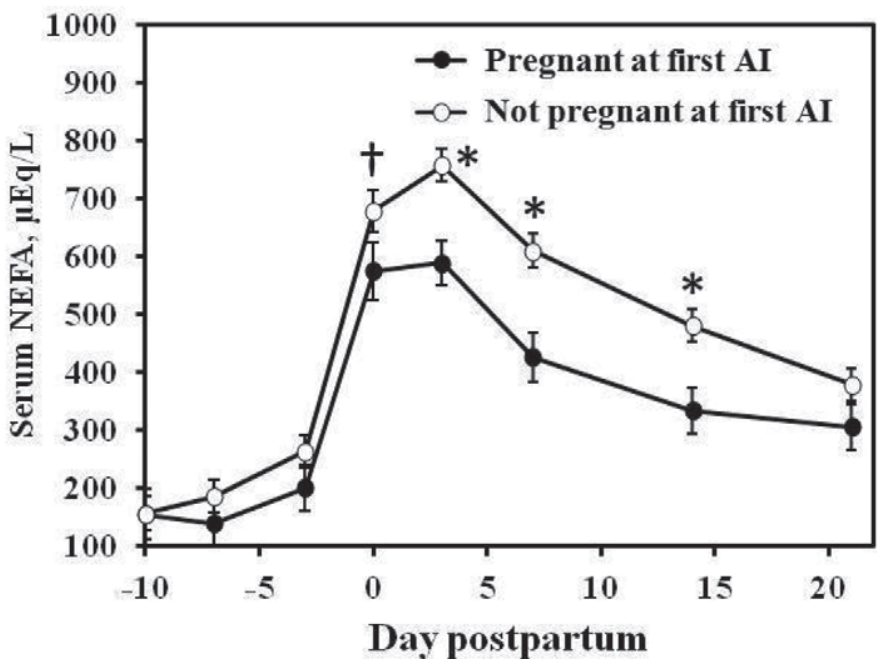

Figure 1. Serum NEFA concentrations (LSM \pm SEM) from d -10 to 21 postpartum in dairy cows that either ovulated (cycling) or had not ovulated (noncycling) by the beginning of the ovulation synchronization program (A) or were either pregnant or not pregnant after first insemination (B). ${ }^{*} P<0.05$ and $\dagger P<0.10$ for the comparison of pregnant and not pregnant on individual days.

were low from 10 to $3 \mathrm{~d}$ before calving, were greatest on the day of calving and on d 3 postpartum, and then decreased on $\mathrm{d} 7,14$, and 21 postpartum (Figure 1). No effect of cyclicity status on serum NEFA concentrations (Figure 1A) was observed. An effect was observed of pregnancy status on serum NEFA concentrations $(P<$ $0.001)$ and a pregnancy status by day interaction $(P<$ 0.05 ; Figure 1B). Serum NEFA were not different prepartum for cows that became pregnant following first insemination compared with those that did not become pregnant. The NEFA concentrations were lower, however, on $\mathrm{d} 3,7$, and $14(P<0.01)$ postpartum in cows that became pregnant compared with cows that were not pregnant following first insemination. The NEFA concentrations tended to differ on the day of calving ( $P$ $=0.084$ ), and were not different on d 21 postpartum.

An effect of day on plasma glucose concentrations $(P<0.001$; Figure 2$)$ was observed. The average concentrations of glucose were between 61 and $64 \mathrm{mg} / \mathrm{dL}$ before calving, increased to over $70 \mathrm{mg} / \mathrm{dL}$ on the day of calving, and decreased following calving. Glucose concentrations were not different between cows that were cycling and cows that were noncycling at any time during the experimental period (Figure 2A). An effect of pregnancy status on mean glucose concentrations $(P<0.01)$ was observed. Mean glucose concentrations during the prepartum period were not different between cows that became pregnant at first insemination compared with those that did not (Figure 2B). Mean glucose concentrations were or tended to be greater, however, on d $0(P<0.01), 3(P<0.03), 7(P<0.07)$, and $21(P<0.07)$ postpartum in cows that became pregnant compared with cows that were not pregnant following first insemination. Plasma glucose was not different at $\mathrm{d} 14$.

Logistic regressions were used to determine the probability of pregnancy based on blood NEFA and glucose concentrations from individual days. The regression models were significant for both NEFA and glucose on d 3 postpartum. The probability of pregnancy at first insemination decreased with increasing NEFA concentrations on d 3 postpartum (Figure $3 \mathrm{~A}$ ). Cows with a NEFA concentration of $400 \mu \mathrm{Eq} / \mathrm{L}$, for example, had a $41 \%$ chance of becoming pregnant at first insemination. Cows with a NEFA concentration of $1,000 \mu \mathrm{Eq} / \mathrm{L}$ had a $25 \%$ chance of pregnancy. The probability of pregnancy at first insemination increased with increasing glucose concentrations on d 3 postpartum (Figure 3B). Cows with a glucose concentration of $60 \mathrm{mg} / \mathrm{dL}$, for example, had a $40 \%$ chance or greater of becoming pregnant at first insemination, whereas those with a glucose concentration of $45 \mathrm{mg} / \mathrm{dL}$ had $21 \%$ chance of pregnancy. Mean concentrations of NEFA and glucose were negatively correlated $(\mathrm{r}=-0.25, P<0.001)$.

\section{BCS and Milk Production}

Body condition score at calving and breeding were greater $(P<0.01)$ for cycling compared with noncycling cows. The change in BCS from calving to first insemination was not different for cycling compared with noncycling cows. Mean BCS ( \pm SEM) at calving, breeding, and the difference between the 2 were 2.86 $\pm 0.03,2.67 \pm 0.03$, and $0.19 \pm 0.03$, respectively, for cycling cows and $2.70 \pm 0.05,2.47 \pm 0.05$, and 0.23 
A

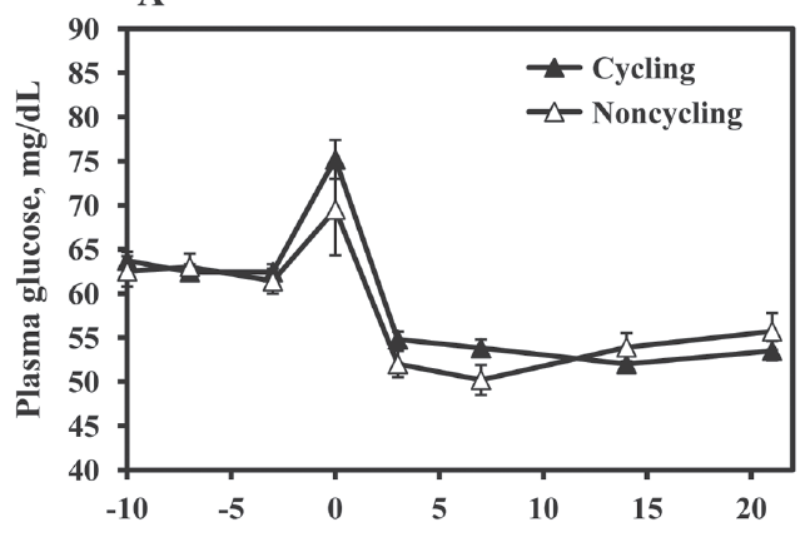

B

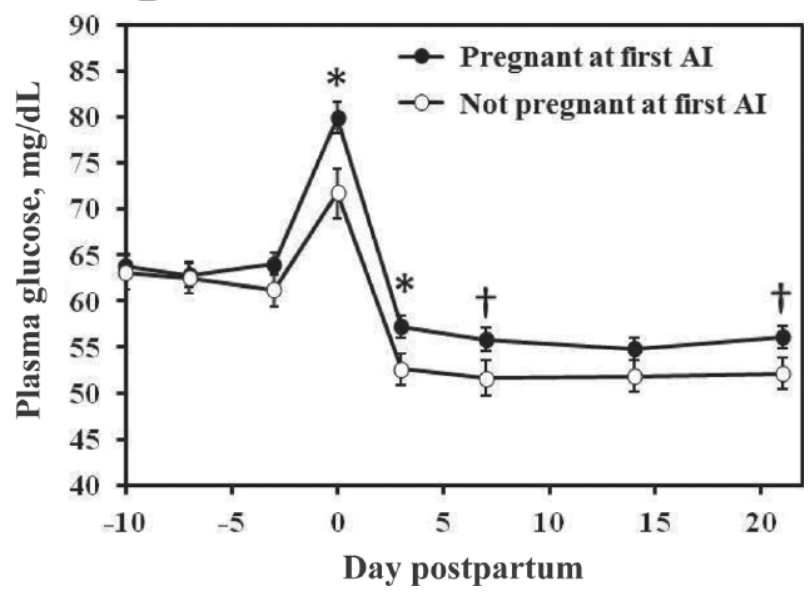

Figure 2. Serum glucose concentrations (LSM \pm SEM) from $d-10$ to 21 postpartum in dairy cows that either ovulated (cycling) or had not ovulated (noncycling) by the beginning of the ovulation synchronization program (A) or were either pregnant or not pregnant after first insemination (B). ${ }^{*} P<0.05$ and $\dagger P<0.10$ for the comparison of pregnant and not pregnant on individual days.

\pm 0.05 , respectively, for noncycling cows. The BCS at calving, breeding, and the difference between the 2 scores were not different for cows that became pregnant at first insemination compared with those that were not pregnant at first insemination. The BCS at calving, breeding, and the difference between the 2 scores for pregnant cows were $2.84 \pm 0.04,2.67 \pm 0.05$, and 0.17 \pm 0.03 , respectively, and $2.80 \pm 0.03,2.59 \pm 0.0,3$ and $0.21 \pm 0.04$, respectively for nonpregnant cows. Daily milk production $(\mathrm{n}=70)$ was not different for cycling $(40.1 \pm 1.2 \mathrm{~kg} / \mathrm{d})$ compared with noncycling cows $(37.8$ $\pm 2.3 \mathrm{~kg} / \mathrm{d}$ ). Daily milk production was not different for cows that became pregnant at first insemination $(39.6 \pm 1.7 \mathrm{~kg} / \mathrm{d})$ compared with those that did not $(39.3 \pm 1.6 \mathrm{~kg} / \mathrm{d})$.
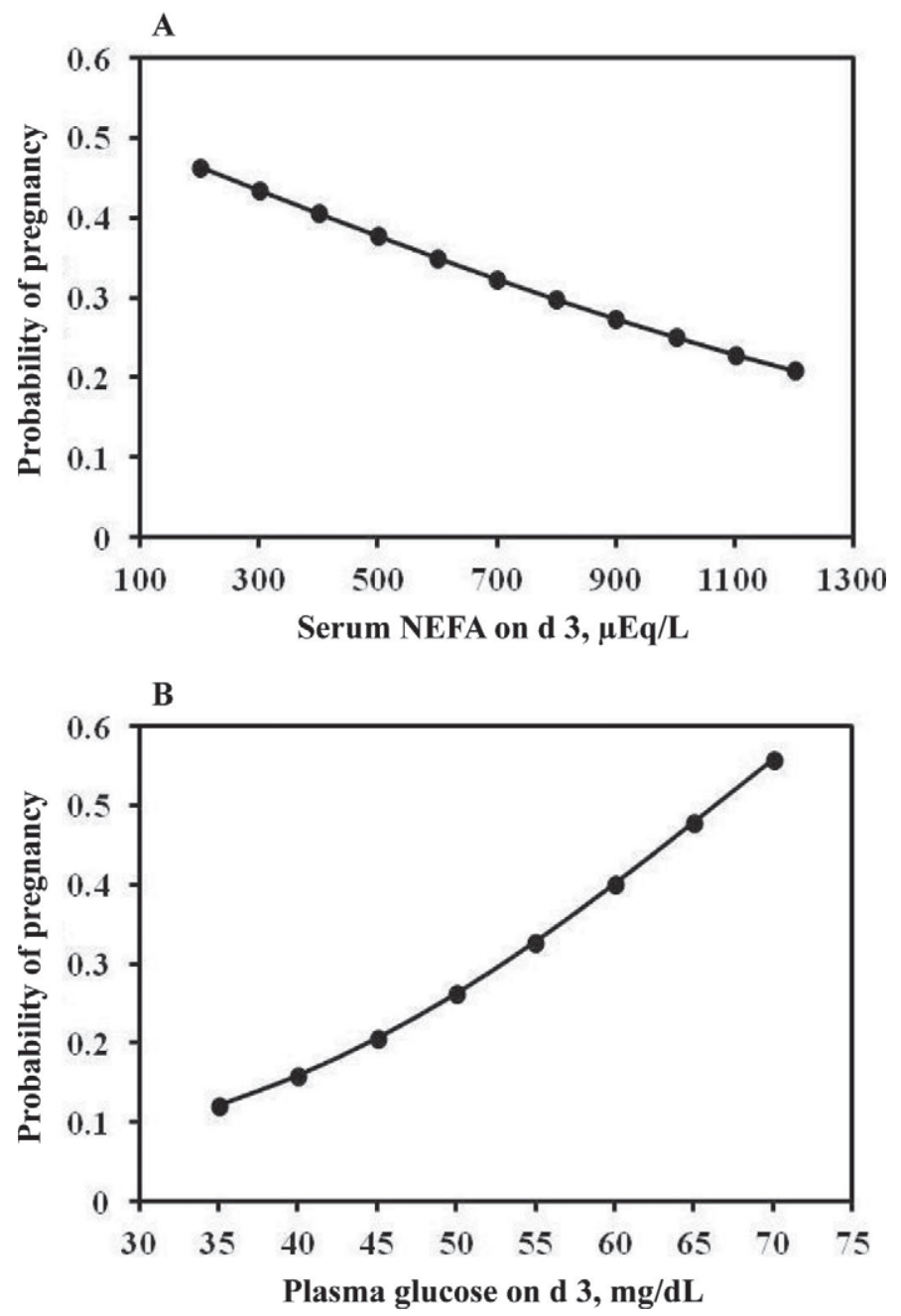

Figure 3. A predictive equation using a predictive logistic regression model from blood NEFA concentrations on d 3 postpartum (A) or blood glucose concentrations on d 3 postpartum (B). Probability of pregnancy $[\mathrm{p}(\mathrm{preg})]$ decreased as blood NEFA concentrations increased $\left[\mathrm{p}(\right.$ preg $)=\left[\mathrm{p}(\right.$ preg $\left.)=\frac{\mathrm{e}^{\left(0.09373-0.001188 \times \mathrm{NEFA}_{\mathrm{d} 3}\right)}}{\left(1+\mathrm{e}^{\left(0.09373-0.001188 \times \mathrm{NEFA}_{\mathrm{d} 3}\right)}\right)}\right]$, whereas the probability of pregnancy increased as blood glucose concentrations increased $\left[\mathrm{p}(\right.$ preg $\left.)=\frac{\mathrm{e}^{\left(-4.2056+0.06341 \times \text { glucose }_{\mathrm{d} 3}\right)}}{\left(1+\mathrm{e}^{\left(-4.2056+0.06341 \times \text { glucose }_{\mathrm{d} 3}\right)}\right)}\right]$.

\section{DISCUSSION}

The current study was conducted to test whether indicators of negative energy balance, increased circulating NEFA, and lower circulating glucose concentrations were associated with cyclicity and also pregnancy after first postpartum insemination. Elevated NEFA concentrations have previously been used as an indicator of negative energy balance in dairy cows (Jorritsma et al., 
2004; Leroy et al., 2004; Beever, 2006). Greater negative energy balance in dairy cows during the postpartum period has been shown to result in a longer interval from parturition to first ovulation and a decrease in first insemination conception rate (Butler and Smith, 1989; Patton et al., 2007). Similar to the current study, elevated concentrations of NEFA (and BHBA) have been associated with a decrease in risk of pregnancy in dairy cows (Ospina et al., 2010b,c). Elevated NEFA and BHBA concentrations have also been associated with a greater incidence of displaced abomasum, clinical ketosis, metritis, and retained placenta (Ospina et al., 2010a). The underlying hypothesis of the current study was based on the established association between postpartum reproduction, negative energy balance, and blood NEFA concentrations. We also added blood glucose to the analyses because, although glucose is not traditionally associated with negative energy balance, it could be a useful indicator, given the large demand for glucose in postpartum cows (Bauman and Currie, 1980). Adequate blood glucose concentrations might be necessary for proper functioning of and preparation of the ovary, oviducts, and uterus subsequent to parturition (Oikonomou et al., 2008; Wathes et al., 2011; Green et al., 2012). As hypothesized, cows that conceived at first insemination had lesser circulating NEFA concentrations compared with cows that did not conceive (Figure 1B). In addition, blood glucose concentrations were greater during the first 3 wk postpartum for cows that conceived at first insemination (Figure 2B).

The current study indicates that energy balance, as indicated by postpartum NEFA, has an effect on P/ $\mathrm{AI}$ at first insemination that occurs at approximately 70 d after calving. Webb et al. (2003) have shown that follicular growth from the primordial stage to the ovulatory phase takes 4 to 5 mo. The effects of negative energy balance, however, likely occur after follicles have entered the growing phase, and thus, the critical window for follicle exposure to negative energy balance may be 6 to 12 wk before ovulation. Lussier et al. (1987) used mitotic indices to calculate that small antral follicles take about 2 estrous cycles (42 d) to reach ovulatory size. Britt (1994) suggested that events that occur during early follicular growth can affect subsequent fertility and, hence, be associated with lowered fertility when cows are inseminated at 70 to $100 \mathrm{~d}$ postpartum. Leroy et al. (2008a,b) recently reviewed the literature and concluded that reduced quality of oocytes and embryos is a factor associated with low conception rates and early embryonic mortality. Fertilization, cleavage, and embryonic development after maturation in vitro are reduced in the presence of NEFA (Jorritsma et al., 2004). Elevated NEFA may also have an effect on the oviduct and uterus. Wathes et al. (2011) have recently shown that cows in severe negative energy balance experience changes in the IGF and insulin signaling pathways that could affect the uterus that is undergoing extensive repair after calving. These changes in growth factor signaling pathways may also limit fetal-uterine interaction necessary for optimum fetal growth and development.

Early postpartum glucose concentrations were greater in cows that conceived at first insemination compared with those that did not conceive (Figure 2B). Green et al. (2012) also found that cows conceiving at first insemination postpartum had greater concentrations of glucose during the first $30 \mathrm{~d}$ postpartum compared with cows that did not conceive to first insemination. Differences in glucose in the current study were greatest on the day of calving, perhaps suggesting that the capacity for glucose production in response to physiological stimuli (in this case, glucocorticoid release at calving) may differ among individual cows. The greater concentration of glucose in the blood may in some manner facilitate uterine involution and prepare the uterus for establishment and maintenance of a pregnancy later postpartum (Wathes et al., 2011). It is also possible that early postpartum glucose imprints the cells of the uterus and ovary so that that they function differently during the breeding period (approximately $60 \mathrm{~d}$ after calving). The specific nature of this metabolic imprinting of the uterus and ovary is unknown at this time but the potential for nutrition to imprint the long-term functional capacity of tissues in the bovine has been demonstrated (Funston et al., 2010). Depressed concentration of glucose in early postpartum lactating cows may be a factor associated with decreased fertility if metabolic imprinting affects the cells of the reproductive tract that initiate development early postpartum and are sustained through the breeding period.

Although blood NEFA and glucose were associated with pregnancy, they were not associated with postpartum cyclicity. We found that neither NEFA (Figure 1A) nor glucose (Figure 2A) concentrations were different in cows that that had initiated ovarian cycles before the timed AI protocol (cycling cows) compared with those that had did not (noncycling cows). We did not monitor cyclicity before $\mathrm{d} 37$. We may have been able to detect differences in blood NEFA and glucose concentrations associated with onset of cyclicity if we had evaluated the cows earlier postpartum. Others have reported a relationship between energy balance and early postpartum cyclicity (Butler and Smith, 1989; Beam and Butler, 1999). The BCS was lower, however, for noncycling compared with cycling cows. Previous studies have shown that BCS (an estimate of adipose tissue mass) during the peripartum period is associated with the length of the postpartum anestrus and 
likelihood of pregnancy (cow with lesser BCS having a longer interval first ovulation and a lesser likelihood of pregnancy; Beam and Butler, 1999; Chagas et al., 2006; Roche, 2006; Roche et al., 2007). In the current study, the mean BCS and the loss in BCS from parturition to first insemination was not different for cows becoming pregnant at first insemination compared with those that did not become pregnant at first insemination. Others have shown that lower BCS at calving and the loss in BCS between calving and first insemination are associated with decreased $\mathrm{P} / \mathrm{AI}$ in dairy cows (Beam and Butler, 1999; Chagas et al., 2006; Roche, 2006; Roche et al., 2007).

\section{CONCLUSIONS}

The observations arising from this study provide evidence that greater blood NEFA concentrations and lesser blood glucose concentrations are found in cows that do not become pregnant at first insemination. These effects were manifest within the first $3 \mathrm{wk}$ postpartum (40 to $60 \mathrm{~d}$ before AI) and could not be explained by correlated effects on the initiation of cyclicity. Early postpartum NEFA and glucose may have coincident effects on reproductive tissues that are undergoing involution (uterus) and reinitiating cyclicity (ovary) shortly after calving. Carryover effects (metabolic imprinting) also might affect the capacity of the cow to become pregnant at a later time. Collectively, the above results suggest that the severity of energy balance that occurs during the early postpartum period $(<3 \mathrm{wk})$ may have a significant effect on the probability of pregnancy at first insemination. Postpartum monitoring of NEFA or glucose could theoretically be used to identify cows at risk for infertility and enable targeted approaches to improve nutritional status and reproductive outcomes.

\section{ACKNOWLEDGMENTS}

The authors acknowledge Dairy Research Farm Manager John Denbigh and Research Specialist Eric Adkins (Columbia, MO) for management and care of the animals used in the experiments.

\section{REFERENCES}

Bauman, D. E., and W. B. Currie. 1980. Partitioning of nutrients during pregnancy and lactation: A review of mechanisms involving homeostasis and homeorhesis. J. Dairy Sci. 63:1514-1529.

Beam, S. W., and W. R. Butler. 1999. Effects of energy balance on follicular development and first ovulation in postpartum dairy cows. J. Reprod. Fertil. Suppl. 54:411-424.

Beever, D. E. 2006. The impact of controlled nutrition during the dry period on dairy cow health, fertility and performance. Anim. Reprod. Sci. 96:212-226.
Britt, J. H. 1994. Follicular development and fertility: Potential effects of negative energy balance. Pages 103-111 in Proc. Natl. Reprod. Symp., Pittsburgh, PA.

Butler, W. R. 2000. Nutritional interactions with reproductive performance in dairy cattle. Anim. Reprod. Sci. 60-61:449-457.

Butler, W. R., and R. D. Smith. 1989. Interrelationships between energy balance and postpartum reproductive function in dairy cattle. J. Dairy Sci. 72:767-783.

Chagas, L. M., J. J. Bass, D. Blache, C. R. Burke, J. K. Kay, D. R. Lindsay, M. C. Lucy, G. B. Martin, S. Meier, F. M. Rhodes, J. R. Roche, W. W. Thatcher, and R. Webb. 2007. Invited review: New perspectives on the roles of nutrition and metabolic priorities in the subfertility of high-producing dairy cows. J. Dairy Sci. 90:4022-4032.

Chagas, L. M., F. M. Rhodes, D. Blanche, P. J. S. Gore, K. A. Macdonald, and G. A. Verkerk. 2006. Precalving feeding and body condition effects on metabolic responses and postpartum anestrus interval in grazing primiparous dairy cows. J. Dairy Sci. 89:19811989.

Funston, R. N., D. M. Larson, and K. A. Vonnahme. 2010. Effects of maternal nutrition on conceptus growth and offspring performance: Implications for beef cattle production. J. Anim. Sci. 88(Suppl.):E205-E215.

Green, J. C., J. P. Meyer, A. M. Williams, E. M. Newsom, D. H. Keisler, and M. C. Lucy. 2012. Pregnancy development from day 28 to 42 of gestation in postpartum Holstein cows that were either milked (lactating) or not milked (not lactating) after calving. Reproduction 143:699-711.

Gumen, A., A. Keskin, G. Yilmazbas-Mecitoglu, E. Karakaya, and M. Wiltbank. 2011. Dry period management and optimization of post-partum reproductive management in dairy cattle. Reprod. Domest. Anim. 46(Suppl. 3):11-17.

Jorritsma, R., M. L. César, J. T. Hermans, C. L. Kruitwagen, P. L. Vos, and T. A. Kruip. 2004. Effects of non-esterified fatty acids on bovine granulosa cells and developmental potential of oocytes in vitro. Anim. Reprod. Sci. 81:225-235.

Kirby, C. J., M. F. Smith, D. H. Keisler, and M. C. Lucy. 1997. Follicular function in dairy cows treated with sustained-release bovine somatotropin. J. Dairy Sci. 80:273-285.

LeBlanc, S. 2010. Monitoring metabolic health of dairy cattle in the transition period. J. Reprod. Dev. 56(Suppl.):S29-S35.

Leroy, J. L., G. Opsomer, A. Van Soom, I. G. Goovaerts, and P. E. Bols. 2008a. Reduced fertility in high-yielding dairy cows: Are the oocyte and embryo in danger? Part I. The importance of negative energy balance and altered corpus luteum function to the reduction of oocyte and embryo quality in high-yielding dairy cows. Reprod. Domest. Anim. 43:612-622.

Leroy, J. L., T. Vanholder, J. R. Delanghe, G. Opsomer, A. Van Soom, P. E. Bols, J. Dewulf, and A. de Kruif. 2004. Metabolic changes in follicular fluid of the dominant follicle in high-yielding dairy cows early post partum. Theriogenology 62:1131-1143.

Leroy, J. L., A. Van Soom, G. Opsomer, I. G. Goovaerts, and P. E. Bols. 2008b. Reduced fertility in high-yielding dairy cows: Are the oocyte and embryo in danger? Part II. Mechanisms linking nutrition and reduced oocyte and embryo quality in high high-yielding dairy cows. Reprod. Domest. Anim. 43:623-632.

Lussier, J. G., P. Matton, and J. J. Dufour. 1987. Growth rates of follicles in the ovary of the cow. J. Reprod. Fertil. 81:301-307.

NRC. 2001. Nutrient Requirements of Dairy Cattle. Natl. Acad. Press, Washington, DC.

Oikonomou, G., G. Arsenos, G. E. Valergakis, A. Tsiaras, D. Zygoyiannis, and G. Banos. 2008. Genetic relationship of body energy and blood metabolites with reproduction in Holstein cows. J. Dairy Sci. 91:4323-4332.

Ospina, P. A., D. V. Nydam, T. Skokol, and T. R. Overton. 2010a. Evaluation of nonesterified fatty acids and $\beta$-hydroxybutyrate in transition dairy cattle in the northeastern United States: Critical thresholds for prediction of clinical diseases. J. Dairy Sci. 93:546-554.

Ospina, P. A., D. V. Nydam, T. Skokol, and T. R. Overton. 2010b. Associations of elevated nonesterified fatty acids and 
$\beta$-hydroxybutyrate concentrations with early lactation reproductive performance and milk production in transition dairy cattle in the northeastern United States. J. Dairy Sci. 93:1596-1603.

Ospina, P. A., D. V. Nydam, T. Skokol, and T. R. Overton. 2010c. Association between the proportion of sampled transition cows with increased nonesterified fatty acids and $\beta$-hydroxybutyrate and disease incidence, pregnancy, and milk production at the herd level. J. Dairy Sci. 93:3595-3601.

Patton, J., D. A. Kenny, S. McNamara, J. F. Mee, F. P. O’Mara, M. G. Diskin, and J. J. Murphy. 2007. Relationships among milk production, energy balance, plasma analytes, and reproduction in Holstein-Friesian cows. J. Dairy Sci. 90:649-658.

Roche, J. F. 2006. The effect of nutritional management of the dairy cow on reproductive efficiency. Anim. Reprod. Sci. 96:282-296.

Roche, J. R., K. A. McDonald, C. R. Burke, J. M. Lee, and D. P. Berry. 2007. Associations among body condition score, body weight and reproductive performance in seasonal-calving dairy cattle. J. Dairy Sci. 90:376-391.

Royal, M. D., J. E. Pryce, A. Woolliams, and A. P. F. Flint. 2002. The genetic relationship between commencement of luteal activity and calving interval, body condition, production and linear type traits in Holstein-Friesian dairy cattle. J. Dairy Sci. 85:3071-3080.
Stevenson, J. S., D. E. Tenhouse, R. L. Krisher, G. C. Lamb, J. E. Larson, C. R. Dahlen, J. R. Pursley, N. M. Bello, P. M. Fricke, M. C. Wiltbank, D. J. Brusveen, M. Burkhart, R. S. Youngquist, and H. A. Garverick. 2008. Detection of an ovulation by heatmount detectors and transrectal ultrasonography before treatment with progesterone in a timed insemination protocol. J. Dairy Sci 91:2901-2915.

Wathes, D. C., Z. Cheng, M. A. Fenwick, R. Fitzpatrick, and J. Patton. 2011. Influence of energy balance on the somatotrophic axis and metalloproteinase expression in the endometrium of the postpartum dairy cow. Reproduction 141:269-281.

Webb, R., B. Nicholas, J. G. Gong, B. K. Campbell, C. G. Gutierrez, H. A. Garverick, and D. G. Armstrong. 2003. Mechanisms regulating follicular development and selection of the dominant follicle. Reprod. Suppl. 61:71-90.

Wildman, E. E., G. M. Jones, P. E. Wagner, R. L. Boman, H. F Troutt Jr., and T. N. Lesch. 1982. A dairy cow body condition scoring system and its relationship to selected production characteristics. J. Dairy Sci. 65:495-501. 